\title{
WINE TOURISM AS AN INCREASINGLY VALUABLE REVENUE STREAM OF A WINERY'S BUSINESS MODEL
}

Katarína Remeňová1, Zuzana Skorková2, Nadežda Jankelová ${ }^{3}$

*Corresponding author E-mail: katarina.remenova@euba.sk

\begin{abstract}
A R T I C LE I N F O
A B S T R A C T

Original Article

Received: 01 January 2019

Accepted: 11 March 2019

doi:10.5937/ekoPolj1901023R

UDC 338.48-53:63]:330.35

Nowadays, wine tourism belongs to the key business activities of a winery. It represents a diversification tool of a typical production company. The research paper aims to explore the relationship between wine tourism and business model parameters according to financial and production performance of a winery. The results of the parametric Independent sample $t$-test reveal that there is no difference

Keywords:

wine tourism, revenue model, revenue streams, winery's revenue, business model

JEL: Q1, M2 in revenue, profit or gross margin between two groups of wineries with or without wine tourism activities. But the analysis gave proof about the difference in a number of revenue streams, key, and additional business activities. The effect size $r$ for $t$ - test was also calculated. Measuring the association between key performance indicators and wine tourism activities reveals the dependency with the number of revenue streams of a winery. Additional business activities are the most relevant parameter to perform better results in wine tourism.
\end{abstract}

(C) 2019 EA. All rights reserved.

\section{Introduction}

Worldwide statistics indicate the size of the vineyards at 7.6 mha. $50 \%$ of the area is managed by the following five key countries only - Spain $14 \%$, China $11 \%$, France $10 \%$, Italy $9 \%$, Turkey $7 \%$. The leading position in the ranch of grapes producers has Europe, as it is shown by other statistics of production (39\% from Europe). Another third is grown in Asia, and $18 \%$ is coming from America. The average wine consumption is currently 242 mhl, with most wine consumers from the US, France, Germany, and Italy (STATE OF THE VITIVINICULTURE WORLD MARKET, 2017)".

1 Katarína Remeňová, Ing., PhD., MBA, Assistant Professor, University of Economics in Bratislava, Dolnozemská cesta 1, 85235 Bratislava, Slovakia, Phone: +421 267295632 , E-Mail: katarina.remenova@euba.sk,

2 Zuzana Skorková, Ing., PhD., Assistant Professor, University of Economics in Bratislava, Dolnozemská cesta 1, 85235 Bratislava, Slovakia, E-Mail: zuzana.skorkova@euba.sk

3 Nadežda Jankelová, Ing., PhD.doc., Associate Professor, University of Economics in Bratislava, Dolnozemská cesta 1, 85235 Bratislava, Slovakia, E-Mail: nadezda.jankelova@euba.sk 
Despite the popularity of wine tourism among customers, it is a research field rather undeveloped. Some research studies provide information on wine tourism activities and destinations or wine tourism characteristics (Alebaki, 2015). In spite of the interest of the customer, this source of income is secondary to wineries (Sevil, Yuncu, 2010). Globally, the wineries state that, on average, $19.5 \%$ of their revenue comes directly from wine tourism. The most common reason why wineries are not involved in wine tourism is the lack of infrastructure to host wine tours, and it would disrupt existing business operations, insufficient economic benefits, lack of knowledge about wine trails, or lack of supply to cope with possible demand (Carlsen \& Charters, 2006).

\section{Literature overview}

Wine tourism represents a crucial complementary activity for a production enterprise such as a winery, thereby completing the specific character of value proposition of a winery. Winery's value is due to wine tourism overflowing through producing industry into the hospitality industry, with the key role of advertising.

Wine tourism refers to group tourism activities, which contain wine tasting and purchasing of wine in wine cellars, visiting wineries, vineyards, and restaurants, including organized wine tours, wine festivals or other special events tailored to company's needs. Last, but not least it supports local rural tourism (Carrà et al., 2016; Mitchell et al., 2012; Santeramo et al., 2017; Bel et al., 2015). The breakthrough in perceiving wine tourism as the importance of wine in making leisure choice brought the study of prof. Coriglianio at Bocconi University. What encouraged the opening of wine routes and, ,open cellars” (Mitchell et al., 2002).

Wine tourism is undoubtedly a vital revenue stream of the business model of a winery, which represents a key sales channel in some tourist areas (Rüdiger \& Hanf, 2017). Also it appears as a significant component of the regional and rural tourism (Asero, Patti, 2011; Skrbic et al. 2015; Krasavac Chroneos et al. 2018), which acts as an attractiveness factor for rural destinations (Meler, 2015) and contributes to the total economic development and employment of a region (Lekić et al., 2018). Also, it is important resource for local economies (Afonso et al., 2018). Business model represents a platform for creating and delivering product value for customers and consists of three key flows - value stream, revenue stream and logistical stream (Osterwalder, Pigneur, 2010). The value for winery's customer is created by a system of activities - key business activities and additional business activities (Zott, Amitt, 2010). The key business activities are the core of the business model, while in the wine industry it comprises production and sale of wine. Additional business activities of wineries include wine tourism activities, events or sale of accessory goods.

To maintain a long-term relationship with customers (Byrd et al., 2016), customer - centric wineries are building loyalty systems with them, providing experiences (Thanh, Kirova, 2018) through providing wine tasting, which is one of the key activities of wine tourism. 
The broad definition of wine tourism is shaping the specification of the wine tourism customer with his / her specific attributes and expectations (Rüdiger et al., 2015), which is used for predicting and promoting future wine tourism based on tourist intentions (Krajíčková, Šauer, 2018). The profile of the wine tourist is similar to that of the wine consumer (Shor, Mansfeld, 2010).

The latest studies addressing the influence of external parameters on wine tourist behaviour such as winescape (Quintal et al., 2015), in combination with the characteristics of wine tourist, using the knowledge for segmentation of the wine tourist (Quintal et al., 2017) such as: specific cultural and geographic (Charters, Ali-Knight 2002), values reflecting on their extrovert and hedonistic lifestyle (Simpson, Bretherton, 2004), destinations offering a wide range of cultural and outdoor attractions (Getz, Brown, 2006) or level of consumer involvement, where four groups of involvement were identified - low-involvement wine tourists, highly involved wine tourists, interestdriven wine tourists, and high-risk perception wine tourists ( $\mathrm{Gu}$ et al., 2018). Sekulic et al. (2017) have monitored Serbian's wine regions and had identified two types of wine tourists - active (consuming wine and visiting winery) and potential (consuming wine).

The logical consequence of customer clustering based on their values and preferences are several studies segmenting models and criteria for wine tourism. Brunner and Siegrist (2011) identified six segments of wine, such as the price-conscious wine consumer; the involved, knowledgeable wine consumer; the image-oriented wine consumer, the indifferent wine consumer; the basic wine consumer; and the enjoyment-oriented, social wine consumer. German researchers have accomplished new segmentation approach based on calculating direct tourism-related sales volume and revenue by selling wine at a winery (Szolnoki, 2018).

\section{Materials and methods}

The goal of this research paper is to explore the relationship between wine tourism activities and business model parameters according to the financial performance of a winery measured by Total revenue, Gross margin, and Profit. However, there are quite enough of production and economic statistics in winery, but in general, there are very few hard statistics on wine tourism. Actual studies in the field of wine tourism are aimed at activities of wine tourism, segmentation criterion, and wine tourism destinations, underlining the importance of wine tourism as a diversifying factor in the wine industry. There are a few studies concerned with the relationship between wine tourism and exact production and financial results impacting a revenue model of a winery (Remeňová, Jankelová, 2018).

The original research sample $(\mathrm{N}=100)$ consists of Slovak wineries of all size types. Consultation with individual wineries and researchers in the winery field led us to focus on thee areas outlined earlier. Publicly available online financial and production information and data (www.finstat.sk) were used in this analysis. The researchers have acquired information also from secondary sources that represent 
the financial statements, annual corporate reports, and studies of external entities. The data obtained through the questionnaire about winery business activities are of a nominal and interval variable.

\section{Data analysis}

The non-parametric Chi Square Test of Independence was used to test the dependence between interval variables (Cultivated area, Annual production, Revenue, Gross Margin, Profit, On the market, No. of Revenue Streams, No. of Offline channels type, No. of Online Channels) and the nominal variables (Own Eshop, Off online channels, Sales channels (direct/indirect), Core business activity, Additional Business activity category, Vineyard Regions). This test is based on the assumption, that nominal variables are employed in the analysis for $\mathrm{r} x \mathrm{c}$ contingency table. Chi-square provide information on the significance level of the observed variables, but also provides detailed information on exactly which categories account for any differences.

The strength of the association was measured through the ETA coefficients and the proportion of variability explained by the nominal variable by $h^{2}$. The Cohen scale was used to interpret the strength of association between variables (Cohen, 1988; Hanák, 2016).

The parametric Independent sample $t$-test was used to identify significant differences in key financial performance indicators, scope of revenue streams, scope of key business activities and scope of additional business activities among two categories of providing/not providing wine tourism activities in a winery. The t-test represents an analysis of dependence, which compares mean value of continuous-level, normally distributed data.

Then the $r$ was examined, whether a difference between two groups is meaningfully large, independent of whether the difference is statistically significant. The effect size $r$ for t- test was then calculated as follows:

$$
r=\sqrt{\frac{t^{2}}{t^{2}+d f}}
$$

The assumption of homogeneity of variance and sphericity assumption was measured through Levenev's test. It represents the homogeneity of variance test that is less dependent on the assumption of normality than most tests. It computes the absolute difference between the value of that case and its cell mean and performs a one-way analysis of variance on those differences.

The data were analysed in PSPP statistical software. Hypotheses were tested at a significance level of $\mathrm{p} \leq 0.05$; while maintaining the primary rule of the Chi-Square Test of Independence, where the theoretical frequencies did not fall below a value of 5 in $80 \%$, and for other values $\mathrm{X}>1$ applied 


\section{Results and discussion}

Based on the descriptive statistical results, we can say that the average number of wine tourism activities is $\mathrm{M}=1.34$. Up to a third of wineries do not carry out any wine tourism activity. Nearly $56 \%$ of enterprises carry out one to two types of tourism activities, contributing to a significant expansion of revenue sources as is presented in Table 1.

Table 1. Frequency table for wine tourism activities

\begin{tabular}{|l|l|l|l|}
\hline wine tourism activities & Frequency & Percent & Cum Percent \\
\hline Non wine tourism activities & 27 & 27.00 & 27.00 \\
\hline One wine tourism activity & 39 & 39.00 & 66.00 \\
\hline Two wine tourism activities & 17 & 17.00 & 83.00 \\
\hline Three wine tourism activities & 8 & 8.00 & 91.00 \\
\hline Four wine tourism activities & 8 & 8.00 & 99.00 \\
\hline Five wine tourism activities & 1 & 1.00 & 100.00 \\
\hline Mean & 1.34 & & \\
\hline Mode & 1.00 & & \\
\hline Median & 1 & & \\
\hline
\end{tabular}

Source: Authors' calculations

The analysis also highlighted the small number of wineries that wine tourism activities consider to be the mainstay of revenue streams and create space for the creative use of this niche segment. 17\% of wineries provide from three to five types of experience activities (Table 2).

Table 2. Descriptive statistics for wine tourism activities

\begin{tabular}{|l|l|l|l|l|l|l|l|l|l|l|l|}
\hline Variable & $\mathbf{N}$ & Mean & $\begin{array}{l}\text { Std } \\
\text { Dev }\end{array}$ & $\begin{array}{l}\text { Vari- } \\
\text { ance }\end{array}$ & $\begin{array}{l}\text { Kur- } \\
\text { tosis }\end{array}$ & $\begin{array}{l}\text { S.E. } \\
\text { Kurt }\end{array}$ & $\begin{array}{l}\text { Skew- } \\
\text { ness }\end{array}$ & $\begin{array}{l}\text { S.E. } \\
\text { Skew }\end{array}$ & Range & Min & Max \\
\hline $\begin{array}{l}\text { wine tourism } \\
\text { activities }\end{array}$ & 100 & 1.34 & 1.24 & 1.54 & .22 & .48 & .94 & .24 & 5.00 & .00 & 5.00 \\
\hline
\end{tabular}

Source: Authors' calculations

The development of wine tourism activities increases the overall interest in traveling and business. Wine tourism interferes with and conditions the activity in gastronomy, the growth of sales channels and the transformation of the business model of the production company - a winery. What is the impact of the offer of services of winemaking on financial indicators (profit, amount of revenue, gross margin)? Is actually there any association with the individual elements of the business model of wineries? According to Newton et al. (2015), direct sales channels influence growth. The results of their study suggest that the distribution channel will have a positive impact on the gross profit margin and winery growth rates. The relation of wine tourism as a direct distribution channel and financial indicators was followed by the next hypotheses:

$\mathrm{H} 0=$ There is no dependence between wine tourism activities and key performance indicators (financial, production) and scope of business model of a winery 
$\mathrm{H} 1=$ There is strong dependence between wine tourism activities and key performance indicators (financial, production) and scope of business model of a winery

The non-parametric Chi Square Test of Independence was used to test the dependences mentioned above. The Eta coefficient measures the relationship between the nominal and the interval variables. The summary results are shown in table 3 .

Table 3. Summary results table for association between Key performance indicators of a winery and Wine tourism activities [ETA; p-value]

\begin{tabular}{|l|l|}
\hline Variables & wine tourism activities yes/no \\
\hline Cultivated area in hectares & .16 \\
\hline \multirow{2}{*}{ Annual production_liters } & .669 \\
\hline Revenue & .14 \\
& .607 \\
\hline Gross Margin & .07 \\
\hline Profit & .491 \\
\hline On the market & .13 \\
\hline \multirow{2}{*}{ No. of Revenue Streams } & .445 \\
\hline Variables & .17 \\
\hline No. of Offline channels type & .498 \\
\hline No. of Online Channels & .00 \\
& .188 \\
\hline
\end{tabular}

Source: Authors' calculations

In support of the hypothesis, we rejected the alternative hypothesis $\mathrm{H} 1$ at the significance level of $\mathrm{p} £ .05$, and accept null hypothesis, because there is no statistically significant dependence in the most researched variables $\mathrm{p}>.05$. Only one dependence can confirm the alternative hypothesis H1. This is the case of No. of Revenue Streams, because of statistically significant dependence with wine tourism activities $\left(\mathrm{p}=.000, \mathrm{~h}^{2}\right.$ $=.348$ ), where variable ,wine tourism activities" explains the moderate proportion of variability in the number of revenue streams. Wineries that expand the range of wine tourism activities create a wider model of revenue.

We also monitored the dependence between wine tourism activities and key elements of business model of a winery. We tested the following hypotheses:

$\mathrm{H} 0=$ There is no dependence between wine tourism activities and elements of business model of a winery

$\mathrm{H} 1=$ There is statistically significant dependence between wine tourism activities and elements of business model of a winery. 
Results are summarized in table 4.

Table 4. Summary results table for association between elements of business model and wine tourism activities [Cramer's V, p-value]

\begin{tabular}{|l|l|}
\hline Variables & wine tourism activities \\
\hline Own Eshop & .05 \\
\hline Off online channels & .615 \\
\hline Sales channels (direct/indirect) & .08 \\
.419 \\
\hline Key business activities & .09 \\
\hline Variables & .350 \\
\hline Additional Business activities & .17 \\
\hline Vineyard Regions & .426 \\
\hline
\end{tabular}

Source: Authors' calculations

Finally, we rejected alternative hypothesis $\mathrm{H} 1$ at the significance level of $\mathrm{p} £ .05$, and accept null hypothesis, because there is no statistically significant dependence in the most researched variables $\mathrm{p}>.05$. Only the variable "Additional Business activities" provide statistically significant result about dependency $(\mathrm{p}=.000, \mathrm{~V}=.33)$, this indicates moderate dependence.

\section{Measurement of differences among wineries, which provide a wine tourism activity}

The parametric Independent sample $t$-test was used to identify significant differences in key financial performance indicators, scope of revenue streams, scope of key business activities and scope of additional business activities among two categories of providing/not providing wine tourism activities in a winery. The following hypotheses were tested:

H0: There is no statistically significant difference in key financial and production performance indicators, scope of revenue streams, scope of key business activities and scope of additional business activities between the groups of wineries, which provide wine tourism activities, and which does not.

H1: There is statistically significant difference in key financial performance indicators, scope of revenue streams, scope of key business activities and scope of additional business activities between the groups of wineries, which provide wine tourism activities, and which does not.

The results of the Levene's test for analyzing the sphericity and homogeneity of variance doesn't confirm the violation of this assumption if $p>.05$. Levene's statistic and data about normality testing are presented in table 5 . 
Table 5. Summary results table for t-test and Homogeneity of variance_wine tourism activities

\begin{tabular}{|c|c|c|c|c|c|}
\hline Variables & No. of wine touris & activit & & & \\
\hline & Levene's Statistic & Sig. & $\mathbf{t}$ & Sig. & $\mathbf{r}$ \\
\hline Cultivated area in hectares & 3.54 & .064 & 1.27 & .208 & - \\
\hline Annual production_liters & 2.36 & .133 & .86 & .397 & - \\
\hline Revenue & .49 & .485 & .69 & .494 & - \\
\hline Gross Margin & 4.48 & .037 & 1.26 & .210 & - \\
\hline Profit & .01 & .962 & 1.62 & .108 & - \\
\hline On the market & .02 & .879 & .01 & .989 & - \\
\hline No. of Revenue Streams & 29.92 & .10 & 7.26 & .000 & .59 \\
\hline No. of Offline channels type & .11 & .745 & 1.84 & .069 & - \\
\hline No. of Online Channels & .18 & .676 & 1.51 & .133 & - \\
\hline $\begin{array}{l}\text { No. of Additional Business } \\
\text { activities }\end{array}$ & 21.43 & .12 & 7.61 & .000 & .61 \\
\hline No. of Key Business activities & 12.03 & .001 & 1.59 & .115 & - \\
\hline
\end{tabular}

Source: Authors' calculations

Based on the results of Independent sample $t$-test, we can state, that, there is no difference between wineries in terms of wine tourism activities in parameters such as - Cultivated area $(\mathrm{t}(98)=1.27, \mathrm{p}=.208)$, Annual production $(\mathrm{t}(98)=.86, \mathrm{p}=.397)$, Revenue $(\mathrm{t}(98)=.69, \mathrm{p}=.494)$, Gross Margin $(\mathrm{t}(98)=1.26, \mathrm{p}=.219)$, Profit $(\mathrm{t}(98)=1.62$, $\mathrm{p}=1.08)$, On the market $(\mathrm{t}(98)=.01, \mathrm{p}=.989)$, No. of Offline channels type $(\mathrm{t}(98)=1.84$, $\mathrm{p}=.069)$, No. of Online Channels $(\mathrm{t}(98)=1.51, \mathrm{p}=.133)$, No. of Key Business activities $(\mathrm{t}(98)=1.59, \mathrm{p}=.115)$. Therefore, we rejected alternative hypothesis $\mathrm{H} 1$ and accepted null hypothesis $\mathrm{H} 0$.

Finally, we find a statistically significant difference in No. of Revenue Streams, $\mathrm{t}(98)=7.26, \mathrm{p}=.000$, with a stronger effect $\mathrm{r}=0.59$, and No.of Additional Business activities, $\mathrm{t}(98)=7.61, \mathrm{p}=.000$, also with a strong effect $\mathrm{r}=.61$, was found in individual groups of the variable Wine tourism activities.

The purpose of our research study was to explore the number and the structure of wine tourism activities as an important part of the business model according to financial and production performance of a winery. At present, wine tourism, from a business model point of view, represents a significant revenue stream and simultaneously refers to direct sales channel, which has an influence on winery's growth. However, the winery industry operates on the same business model, wineries differ in the scope of the revenue model. Almost $40 \%$ of wineries provide at least one wine tourism activity.

Most of wineries are still looking at wine tourism as a minority source of income that can overcome the critical financial period. They do not look for a competitive advantage in it that would create added value for the customer. According to our findings, a third 
of wineries do not offer wine tourism services at all. Wine tourism refers to tourism whose purpose includes visiting vineyards, wineries, wine festivals and events, during which the tasting and consumption of wine and experiencing the attributes of the winegrowing region are the primary motivations.

We asked the question if wineries providing the wine tourism activities have higher sales and higher gross margin. This assumption has not been confirmed. The range of wine tourism services is not so extensive in Slovakia that it should have a statistically significant financial impact on the revenue model.

Although no interaction between the six parameters (No. of Offline channels type, No. of Online Channels, Cultivated area in hectares, Annual production, Revenue, Gross Margin, On the market and Profit) emerged.

\section{Conclusions}

Winery business provides two types of product. There are goods also experienced as a wine tourism activity. In Slovak conditions, wineries primarily offer activities of wine tourism such as wine tasting, accommodation, gastronomy, and events. Despite this activity structure, there are still some wineries, which do not provide any wine tourism activity (up to a third of wineries). The key business activities represent a fundamental pillar of the business model of a winery. The relation to the next element of a business model is crucially significant - how the value for the customer is created. The dependence of the components of the business model and the services offered by the wine tourism indicate to be statistically non-significant. We have also analysed the results of the financial and production indicators; they have proven to be statistically non-significant. Using the parametric Independent sample t-test to identify significant differences in key financial performance indicators, the scope of revenue streams, scope of key business activities and range of additional business activities among two categories of - providing/not providing wine tourism activities in a winery. We found, with strong evidence, that wineries with extended revenue model by wine tourism activities reached a broader scope of additional business activities as well as the broader scope of revenue model (regarding revenue streams).

Importantly, our findings indicate, that wineries with well-defined revenue model extended by wine tourism are more likely to identify opportunities for developing new revenue sources.

\section{Limitation of the study}

The results of the research study provide answers to the existence of an innovative revenue stream of a winery regarding wine tourism and its impact on partial financial and production indicators and business model elements. Despite primary results, we realize the research limitation by a single industry of only one country. We consider the next research should be intensely focused on the financial performance of each revenue stream of the revenue model to ensure increasing profitability of a winery. It 
would also be efficient to extend the statistical sample of other wineries in Slovakia and neighboring countries because the business model of these enterprises is the same, but it differs within the scope of the revenue model.

\section{Acknowledgements}

The authors are thankful to VEGA No.: 1/0109/17 The innovative approaches to management and their influence on the competitiveness and the successfulness of the companies within the conditions of the global economy for financial support to carry out this research.

\section{Conflict of interests}

The authors declare no conflict of interest.

\section{References}

1. Afonso, C., Silva, G.M., Goncalves, H.M., Duarte, \& M. (2018). The role role of motivations and involvement in wine tourists' intention to return: SEM and fsQCA findings. Journal of business research, 89, 313-321. DOI: 10.1016/j. jbusres.2017.11.042

2. Alebaki,M.,Menexes, G.,\&Koutsouris,A.(2015).Developing amultidimensional framework for wine tourist behavior: Evidence from Greece. Wine Economics and Policy, 4 (2), 98-109. https://doi.org/10.1016/j.wep.2015.11.002

3. Asero, V., \& Patti, S. (2011). Wine tourism experience and consumer behavior: the case of sicily. Tourism analysis, 16(4), 431-442. DOI: 10.3727/108354211X 13149079788936

4. Bel, F., Lacroix, A., Lyser, S., Rambonilaza, T., \& Turpin, N. (2015). Domestic demand for tourism in rural areas: Insights from summer stays in three French regions. Tourism Management, 46, 562-570. https://doi.org/10.1016/j. tourman.2014.07.020

5. Brunner, T.A., \& Siegrist, M. (2011). A consumer-oriented segmentation study in the Swiss wine market. British food journal, 113(2-3), 353-373. DOI: 10.1108/00070701111116437

6. Byrd, E., T., Canziani, B., Hsieh, Y., Debbage, K., \& Sonmez, S. (2016). Wine tourism: Motivating visitors through core and supplementary services. Tourism Management, 52, 19-29. https://doi.org/10.1016/j.tourman.2015.06.009

7. Carlsen, J., \& Charters, S. (2006). Global Wine Tourism: Research, Management and Marketing. CAB International, Wallingford.

8. Carrà, G., Mariania, M., Radić, I., \& Peri, I. (2016). Participatory Strategy Analysis: The Case of Wine Tourism Business. Agriculture and Agricultural Science Procedia, 8, 706-712. https://doi.org/10.1016/j.aaspro.2016.02.050 
9. Getz, D., \& Brown, G. (2006). Critical success factors for wine tourism regions: a demand analysis. Tourism Management, 27(1), 146-158. https://doi. org/10.1016/j.tourman.2004.08.002

10. Gu, Q.S., \& Zhang, H.Q.Q., King, B., \& Huang, S.S. (2018). Wine tourism involvement: a segmentation of Chinese tourists. Journal of travel \& tourism marketing, 35(5), 633-648. DOI: 10.1080/10548408.2017.1401031

11. Hall, C., M., Cambourne, B., Sharples, L., \& Macionis, N. (2002). Wine Tourism Around the World: Development, Management and Markets. Butterworth Heinemann, Oxford.

12. Krajíčková, A., \& Šauer, M. (2018). Differences in motivation of food festivals visitors - A view from the Czech Republic. Geographica Pannonica, 22(3), 189200. DOI: $10.5937 / \mathrm{gp} 22-17050$

13. Krasavac Chroneos, B., Katica, R., \& Bradic-Martinovic, A. (2018). SWOT analysis of the rural tourism as a channel of marketing for agricultural products in Serbia. Economics of Agriculture, 65(4), 1573-1584. DOI: https://doi. org/10.5937/ekoPolj1804573K

14. Lekić, N., Savić, G., Knežević, S., \& Mitrovic, A. (2018). The efficiency analysis in small wineries in the Republic of Serbia. Economics of Agriculture, 65(4), 1529-1544. DOI: https://doi.org/10.5937/ekoPolj1804529L

15. Meler, M. (2015). Wine tourism as a centripetal force in the development of rural tourism. 3rd International scientific conference tosee - tourism in southern and eastern europe 2015: sustainable tourism, economic development and quality of life, Opatija, 197-209. Retrieved from http://apps.webofknowledge. com.bukz2too0b0b.han2.savba.sk/full_record.do?product=WOS\&search mode $=$ GeneralSearch \&qid $=1 \& \mathrm{SID}=6 \mathrm{BBnCipFnfcljuklpm} 3 \&$ page $=1 \& \mathrm{doc}=1$

16. Mitchell, R., Charters, S., \& Albrecht, J., N. (2012). Cultural systems and the wine tourism product. Annals of Tourism Research, 39(1), 311-335. https://doi. org/10.1016/j.annals.2011.05.002

17. Newton, S., K., Gilinsky, A., Jr., \& Jordan, D. (2015). Differentiation strategies and winery financial performance: An empirical investigation. Wine Economics and Policy, 4(2), 88-97. https://doi.org/10.1016/j.wep.2015.10.001

18. Osterwalder, A., \& Pigneur, Y. (2010). Business model generation: A handbook for visionaries, game changers, and challengers. John Wiley \& Sons, Hoboken.

19. Quintal, V., A., Thomas, B., \& Phau. I. (2015). Incorporating the winescape into the theory of planned behaviour: Examining 'new world' wineries. Tourism Management, 46, 596-609. https://doi.org/10.1016/j.tourman.2014.08.013

20. Quintal, V., Thomas, B., Phau, I., \& Soldat, Z. (2017). Using push-pull winescape attributes to model Australian wine tourist segmentation. INTERNATIONAL JOURNAL OF WINE BUSINESS RESEARCH, 29(4), 346-372. DOI: 10.1108/ IJWBR-01-2017-0007 
21. Remeňová, K., \& Jankelová, N. (2018). Multiple revenue streams model of wineries. Fourth international scientific conference knowledge based sustainable economic development ERAZ 2018, Sofia, 222-229. Retrieved from http://www. eraz.org.rs/home.html

22. Rüdiger, J., \& Hanf, J.H. (2017). Wine tourism as an instrument of direct sales in the wine sector. Berichte uber Landwirtschaft, 95 (2), 1-24.

23. Rüdiger, J., Hanf, J.H., \& Schweickert, E. (2015). The expectation of the behaviour of wine tourists in Germany. Reports about agriculture, 93(2), 1-23, Bonn. [in German: Rüdiger, J., Hanf, J.H., Schweickert, E. (2015). Die Erwartungshaltung von Weintouristen in Deutschland. Berichte über Landwirtschaft - Zeitschrift für Agrarpolitik und Landwirtschaft, 93(2), 1-23.

24. Santeramo, F., G., Seccia, A., \& Nardone, G. (2017). The synergies of the Italian wine and tourism sectors. Wine Economics and Policy, 6(1), 71-74. https://doi. org/10.1016/j.wep.2016.11.004

25. Sekulic, D., Petrovic, A., \& Dimitrijevic, V. (2017). Who are wine tourists? An empirical investigation of segments in serbian wine tourism. Ekonomika poljoprivreda-economics of agriculture, 64(4), 1571-1582.

26. Sevil, G., \& Yüncü, H.R. (2010). Wine producers' perceptions of wine tourism. Tourism, 57(4), 477-487.

27. Shor, N., \& Mansfeld, Y. (2010). Between wine consumption and wine tourism: Consumer and spatial behavior of Israeli wine tourists. Tourism, 57(4), 381-403.

28. Skrbic, I., Jegdic, V., Milosevic, S., \& Tomka, D. (2015). Development of sremski karlovci wine tourism and integration in the regional tourism offer. Ekonomika poljoprivreda-economics of agriculture, 62(1), 229-244. DOI: 10.5937/ekoPolj1501229S

29. Szolnoki, G. (2018). New approach to segmenting tourists in a German wine region. International journal of wine business research, 30(2), 153-168. DOI: 10.1108/IJWBR-07-2017-0044

30. STATE OF THE VITIVINICULTURE WORLD MARKET, Retrieved from: http://www.oiv.int/public/medias/5287/oiv-noteconjmars2017-en.pdf, (December 12, 2018)

31. Thanh, T, \& Kirova, V. (2018). Wine tourism experience: A netnography study. Journal of Business Research, 83, 30-37. https://doi.org/10.1016/j. jbusres.2017.10.008

32. Zott, Ch., \& Amit, R. (2010). Business Model Design: An Activity System Perspective. Long Range Planning, 43(2-3), 216-226. https://doi.org/10.1016/j. $\underline{\text { lrp.2009.07.0047 }}$ 